\title{
Linear Attenuation as an Indicator for Safe Water
}

\author{
M. U. Mgbukwu ${ }^{1, *}$, L. D. Christopher ${ }^{1}$ and A. J. Iseh ${ }^{2}$ \\ ${ }^{1}$ Department of Physics, University of Jos, Plateau State, Nigeria \\ ${ }^{2}$ Department of Pure and Applied Physics, Federal University Wukari, Taraba State, Nigeria \\ ${ }^{*}$ Corresponding author
}

\begin{abstract}
This study analyses the linear attenuation coefficient as an indicator for safe water, the study was carried out using various water samples from borehole, well and pond in two Local Government Areas namely, Jos North and Jos East areas of Plateau State, Nigeria. The samples were collected in a Perspex of volume $7 \mathrm{~cm} \times 7 \mathrm{~cm} \times 7 \mathrm{~cm}$ and filled to a height of $3 \mathrm{~cm}$. Energy of $70 \mathrm{kVp}$ of X-ray was passed through the samples with an X-ray detector under the Perspex of water to get the different final X-ray doses. From the study the linear attenuation coefficient ranges from $0.2878 \mathrm{~cm}^{-1}-0.4270 \mathrm{~cm}^{-1}, 0.3074 \mathrm{~cm}^{-1}-0.4743 \mathrm{~cm}^{-1}$, $0.3074 \mathrm{~cm}^{-1}-0.4743 \mathrm{~cm}^{-1}$ for borehole, well and pond in that order. The study showed a strong correlation between the linear attenuation coefficient and turbidity, total hardness and density which follows a trend for different samples. The highest value of linear attenuation ranges from borehole, well, pond in that order. This study was able to get a value of linear attenuation coefficient for safe water which ranges from $0.40203 \mathrm{~cm}^{-1}$ $0.02414 \mathrm{~cm}^{-1}$ which can be used to ascertain the quality of water.
\end{abstract}

\section{Introduction}

Linear attenuation coefficient $(\mu)$ is the fraction of incident photon per unit distance. It plays a vital role in determining researchers' problems and possible solutions of physical science, radiation dosimetry, and medical physics. X-ray attenuation yield information on the material composition such as thickness, density and water content etc. Received: August 7, 2019; Accepted: September 13, 2019

Keywords and phrases: water samples, linear attenuation, X-ray, atomic absorption spectroscopy (AAS).

Copyright (C) 2019 M. U. Mgbukwu et al. This is an open access article distributed under the Creative Commons Attribution License, which permits unrestricted use, distribution, and reproduction in any medium, provided the original work is properly cited. 
Kirandeep et al. [8]. X-ray irradiation is used in many fields of study like medicine, food, preservation and measuring technique.

According to Biradar and Dongarge [5] the linear attenuation coefficient for ammonium sulfate salt by aqueous solution method using gamma energy. Linear attenuation coefficient of X-ray on different materials such as concrete, soil and even sugar solutions. This has really broadened researchers mind in developing several models for shielding materials.

Water is very important in the activities of living things, the quality of water is of great importance to man; a good water must have the following characteristics; odourless, tasteless, and colourless (Food \& Agricultural Organization [6]). To ascertain the quality and purity of water is of great importance to any scientific study, the contamination of water is as a result of disease causing microorganisms, harmful physical and chemical materials (Aremu et al. [4], Abimbola et al. [1], Achadu et al. [2]). Therefore it is certain that periodic water analysis must be conducted to ascertain the quality of water. Some spectroscopic method have been used to determine the purity and quality of water through the following physical properties such as $\mathrm{pH}$, temperature, turbidity, total hardness, conductivity, suspended solids, etc. the purity and quality of water cannot be ascertain by just a single method of study.

The main objective of this study is to use linear attenuation as an indicator for safe water. This is a comparative study of the various means of determining the purity of water; it determines the penetrative power of X-ray in water. The water samples were collected from different sources in Jos East and Jos North Local Government Area of Plateau State. The water samples from their different sources were analyzed for their psycho- chemical, heavy metals and linear attenuation in other to identify potential contaminant.

\section{Study Area}

The two study areas, Jos North and Jos South are located in Plateau State. The Lies on the coordinates area bounded between longitude $8^{\circ} 31^{\prime} \mathrm{E}$ to $8^{\circ} 59^{\prime} \mathrm{E}$ and latitude $9^{\circ} 34^{\prime} \mathrm{N}$ to $9^{\circ} 55^{\prime} \mathrm{N}$. The vegetation of the study area is that of savannah zone and has two climate seasons wet (April-October) and the dry season (November-March). A major part of the Jos Plateau is underlain by non-orogenic granites of the Mesozioc Era generally known as the younger granites. 


\section{Theory}

The attenuation of water depends upon mass per unit area of the water. The intensity of transmitted X-ray radiation through water is given as

$$
I=I_{0} e^{-\mu x}
$$

where $I=$ Transmittance

$I_{0}=$ Incidence ray

$\mu=$ Linear attenuation coefficient

$x=$ Thickness of sample.

The mass attenuation coefficient was calculated using the values gotten from linear attenuation coefficient and it was given by the expression

$$
\text { Mass attenuation coefficient of water samples }=\frac{\mu}{\rho} \text {, }
$$

where $\mu=$ Linear attenuation coefficient

$\rho=$ Density of water sample.

From Hubbell's rule [7], the mass attenuation coefficient of gamma rays in water is assumed to depend upon the sum of the cross section presented by all the atoms. It is represented as

$$
\frac{\mu}{\rho}=\sum_{i} W_{i}\left(\frac{\mu}{\rho}\right)
$$

Using the data the experimental linear attenuation coefficient of the water sample $\left(\mu_{\exp }\right)$ is obtained from,

$$
\mu_{\exp }=\frac{1}{x} \operatorname{Ln}\left(\frac{I_{0}}{I}\right)
$$

where $x$ is the height of the sample.

The percentage error is given as $\frac{\mu_{\mathrm{th}} \times \mu_{\mathrm{exp}}}{\mu_{\mathrm{th}}}$. 
Attenuation for water is obtained from Hubbell table by multiplying its density we get theoretical $\mu_{\mathrm{th}}$ for water. The graph of $\mu_{\exp }\left(\mathrm{cm}^{-1}\right)$ versus turbidity, total hardness, $\mathrm{pH}$ and density was plotted at $70 \mathrm{kVp}$ X-ray. The $\mu_{\text {th }}$ of the water sample used from Hubbell's rule was 1.061E-01.

\section{Sampling and Analysis}

Fifteen samples of water (five wells, five boreholes and five ponds) each from the study area were collected in January 2018. This period was chosen because it represents the peak of the dry season. Prior to the sampling all bottles were cleaned and properly rinsed with $\mathrm{H}_{2} \mathrm{SO}_{4}$ to disinfect the container and then rinsed with water sample of that source to be analyzed; the collected samples were properly labeled and transported to the laboratory for analysis. Mine ponds, well and borehole samples were collected in 4 litres plastic and it was taken to the laboratory were the heavy metal concentration (ppm) was determined using atomic absorption spectrophotometer (UNICAM 929) presented in Table 1. At every location, were the water was collected the surface radiation dose was measured at the surface and 1 meter above the surface using a Gamma Scout (W/alert version) radiation meter They samples were analyzed for turbidity, density, alkalinity test, total hardness, $\mathrm{pH}$ test, conductivity, and suspended solids according to standard methods described in APHA (1998). An Etrex Garmin Global position system (GPS meter) was used to obtain coordinates and locations of the sampling points. The temperature of the water samples were recorded at the site of the collection using calibrated thermometer.

\section{Experimental Procedure for Attenuation Coefficient}

The experiment was carried out at the Radiology Department of Jos University Teaching Hospital (JUTH). An electrometer was used to determine the record of the counting in the control room. It is made up of two linear collimators: one at the front of the ionization chamber and another for the X-ray source. Linear attenuation of all the water samples was determined by measuring $135 \mathrm{ml}$ of each water sample into Perspex designed in a square shape of dimensions of $(7 \times 7 \times 7) \mathrm{cm}^{3}$, the Perspex was used because it has similar atomic number with that of water. The water was poured in the Perspex to a depth of $3 \mathrm{~cm}$. The water sample was placed between two collimators each of aperture of $1.2 \mathrm{~mm}$ at a distance of $100 \mathrm{~cm}$ from the X-ray source, a stool was constructed of $30 \mathrm{~cm}$ 
height, with two strata, the top stratum having an opening of $10 \times 10 \mathrm{~cm}$, this is to allow $\mathrm{X}$-ray beam penetrate the water samples and reaches the X-ray detector which is placed on the second stratum $20 \mathrm{~cm}$ below the first, thus the $\mathrm{X}$-ray detector is placed $10 \mathrm{~cm}$ above the X-ray couch. The distance between the instadose detector and the couch is $10 \mathrm{~cm}$, the distance between the detector and the sample is $20 \mathrm{~cm}$, and the distance between the $\mathrm{X}$-ray tube and the sample is $70 \mathrm{~cm}$. Samples were subsequently placed between the $\mathrm{X}$-ray source and the detector at linear collimator geometry under open wheel (without filter). X-ray source of energies $70 \mathrm{kVp}$ were irradiated on each sample for $20 \mathrm{mAs}$ by this procedure, the intensity of the direct $\left(I_{0}\right)$ and the transmitted $(I)$ flux were determined and the counting was recorded by the electrometer.

\section{Results and Discussion}

Table 1 shows the heavy metal concentrations (ppm) in the water samples (well, ponds, borehole). The concentration of heavy metals vary from different source of water, it was observed that the pond sample MU11 and MU15, the concentration of lead where higher than the Environmental Protection Agency maximum concentration of $0.1 \mathrm{mgL}^{-1}$, high concentration of lead is toxic to humans and to aquatic life, high intake of it will cause hypertension, brain damage, tiredness, irritability, anemia and behavioral changes of children. In sample MU12, MU13 and MU14 it was observed with high amount of chromium which is higher than the SON standard of $0.1 \mathrm{mgL}^{-1}$ which can lead to necrosis nephrites, death, and irritation of the gastrointestinal mucosa. There was high amount of mercury concentration in MU09, MU13, MU14, MU08, this concentration were higher than the SON standard of $0.002 \mathrm{mgL}^{-1}$ which can result in the following effect, its poisonous, mutagenic effects and it disturbs the cholesterol. It was also seen that sample MU08, MU09, MU11 and MU15 has high amount of copper which is more than the SON standard of $1.0 \mathrm{mgL}-1$ which can cause damage to the aquatic fauna, phytotoxic, mucosal irritation and corrosion (Adekunle et al. [3]). Generally, the amount of metals in the water increased in the order Pond $>$ Well $>$ Borehole. The high level of metals in pond samples is as a result of rampant dumping of wastes and mining activities done around the pond sites.

The results of the physicochemical parameters for all the water samples and their geographical coordinate were presented in Table 2. The $\mathrm{pH}$ of the water samples were determined using a $\mathrm{pH}$ meter to determine the alkalinity/ acidity of the sample and it 
ranges from 5.0-6.31 for MU01-MU05, 4.35-5.67 for MU06-MU10, and 5.73-6.15 for MU11-MU15 respectively. According to Pawar et al. [9] any water that has a $\mathrm{pH}$ more than 9 and less than 4.5 is suitable for use. $\mathrm{pH}$ sample gotten were not in the range of SON standard specification, which is 6.5-8.5. The temperature which is the key factor that affects the aquatic biochemical reactions was observed from $24^{\circ} \mathrm{C}-28.2^{\circ} \mathrm{C}$. The turbidity value was gotten using a turbidity meter in (NTU), it ranges from 1.06-4.46, 1.03-8.4 and 4.23-5.31 for sample MU01-MU05, MU06-MU10 and MU11-MU15 respectively. According to SON guidelines, the maximum amount of total hardness is 100 $\mathrm{mgL}^{-1}$, sample MU02, MU04, MU06, MU08, MU09, MU011 and MU015 exceeded the standard limit slated by SON.

Table 1. Metal concentration (ppm) in water samples from wells, boreholes and ponds.

\begin{tabular}{|c|c|c|c|c|c|c|c|c|c|c|c|c|c|c|c|c|}
\hline Mineral & MU01 & MU02 & MU03 & MU04 & MU05 & MU06 & MU07 & MU08 & MU09 & MU10 & MU 11 & MU12 & MU13 & MU14 & MU15 & $\begin{array}{c}\text { SON } \\
\text { Standard }\end{array}$ \\
\hline $\mathrm{Cd}$ & 0.0012 & 0.0011 & 0.0016 & 0.0018 & 0.0012 & 0.0024 & 0.0021 & 0.0028 & 0.0022 & 0.0030 & 0.0024 & 0.0027 & 0.0027 & 0.0026 & 0.0025 & 0.003 \\
\hline $\mathrm{Pb}$ & 0.0044 & 0.0046 & 0.0041 & 0.0040 & 0.0042 & 0.0171 & 0.0174 & 0.0176 & 0.0173 & 0.0194 & 0.1965 & 0.2317 & 0.1966 & 0.1977 & 0.2138 & 0.010 \\
\hline $\mathrm{As}$ & 0.0009 & 0.0007 & 0.0010 & 0.0008 & 0.0006 & 0.0020 & 0.0022 & 0.0029 & 0.0021 & 0.0028 & 0.0039 & 0.0040 & 0.0038 & 0.0037 & 0.0039 & $0 . .010$ \\
\hline $\mathrm{Fe}$ & 0.1266 & 0.1267 & 0.2284 & 0.0269 & 0.2770 & 0.4410 & 0.4140 & 0.4137 & 0.4351 & 0.4450 & 0.0684 & 0.0688 & 0.0676 & 0.0677 & 0.0668 & 0.300 \\
\hline $\mathrm{Cu}$ & 0.0004 & 0.0003 & 0.0004 & 0.0003 & 0.0005 & 0.0013 & 0.0012 & 2.3006 & 1.8366 & 2.4502 & 1.4087 & 0.0055 & 0.0047 & 0.0048 & 2.5544 & 1.000 \\
\hline $\mathrm{Hg}$ & 0.0001 & 0.0003 & 0.0002 & 0.0001 & 0.0002 & 0.0001 & 0.0002 & 0.0154 & 0.0223 & 0.0001 & 0.0004 & 0.0003 & 0.0455 & 0.0340 & 0.0004 & 0.001 \\
\hline $\mathrm{Mn}$ & 0.0094 & 0.0082 & 0.0088 & 0.0098 & 0.0088 & 0.0233 & 0.0235 & 0.0248 & 0.2330 & 0.0244 & 0.0362 & 0.0366 & 0.0380 & 0.0388 & 0.0382 & 0.200 \\
\hline
\end{tabular}

MU01=DU(borehole), MU02=Gadabiyu(borehole), MU03=juth(borehole), MU04=Angul Dee(borehole), MU05=Yan trailer(borehole), MU06=jenta(well), MU07=St. murumba(well), MU08=Tudunwada(well), MU09=Sot Gyel(well), MU10=Bauchi junction(well), MU11=Ray field resort(pond), MU12=Zawan(pond), MU13=TCNN(pond), MU14=Sot Gyel(pond), MU15=Angul Dee(pond)

Table 2. Table showing the value of the masses, volume, density, and physico-chemical properties of various locations.

\begin{tabular}{|c|c|c|c|c|c|c|c|c|c|c|c|}
\hline \begin{tabular}{|l} 
Sample \\
ID
\end{tabular} & Location & $\begin{array}{l}\text { Geographical } \\
\text { Coordinate }\end{array}$ & \begin{tabular}{|l} 
Temp. \\
$\left({ }^{\circ} \mathrm{C}\right)$
\end{tabular} & \begin{tabular}{|l}
$\begin{array}{l}\text { Volume } \\
(\mathrm{mL})\end{array}$ \\
\end{tabular} & \begin{tabular}{|l} 
Thick- \\
ness \\
$(\mathbf{c m})$
\end{tabular} & \begin{tabular}{|l} 
Mass \\
(g)
\end{tabular} & $\begin{array}{l}\text { Density } \\
(\mathrm{g} / \mathrm{mL})\end{array}$ & pH & \begin{tabular}{|l|}
$\begin{array}{l}\text { Turbidity } \\
\text { (NTU) }\end{array}$ \\
\end{tabular} & \begin{tabular}{|l|} 
Total \\
Hardness \\
$\left(\right.$ MgL $\left.^{-1}\right)$
\end{tabular} & \begin{tabular}{|l|} 
Suspended \\
Solids \\
$\left(\mathrm{MgL}^{-1}\right)$
\end{tabular} \\
\hline MU01 & Du & NA & 28.000 & 135.0000 & 3.0000 & 109.7360 & \begin{tabular}{|l|}
0.8129 \\
\end{tabular} & 5.2800 & 1.1200 & 80.0000 & 0 \\
\hline MU02 & GadaBiyu & $\begin{array}{l}09^{\circ} 55^{\prime}, 44^{\prime \prime} \mathrm{N} \\
08^{\circ} 52^{\prime}, 18^{\prime \prime} \mathrm{E}\end{array}$ & 28.20 & 135.0000 & 3.0000 & 109.8400 & 0.8136 & 5.2700 & 4.4600 & 108.0000 & 0 \\
\hline MU03 & JUTH & $\begin{array}{l}09^{\circ} 54^{\prime} 59^{\prime \prime} \mathrm{N} \\
08^{\circ} 53^{\prime} 27^{\prime \prime} \mathrm{E}\end{array}$ & 28.300 & 135.0000 & 3.0000 & 105.9100 & 0.7845 & 5.0000 & 1.1000 & 60.0000 & 0 \\
\hline MU04 & Angul Dee & NA & 25.000 & 135.0000 & 3.0000 & 125.1000 & 0.9267 & 5.9100 & 5.3100 & 186.0000 & 1 \\
\hline
\end{tabular}




\begin{tabular}{|c|c|c|c|c|c|c|c|c|c|c|c|}
\hline MU05 & Yan Trailer & NA & 26.000 & 135.0000 & 3.0000 & 105.0000 & 0.7778 & 6.3100 & 1.0600 & 72.0000 & 0 \\
\hline MU06 & JENTA & $\begin{array}{l}9^{\circ} 55^{\prime} 77^{\prime \prime} \mathrm{N} \\
8^{\circ} 52^{\prime} 46^{\prime \prime} \mathrm{E}\end{array}$ & 27.000 & 135.0000 & 3.0000 & 121.2100 & 0.8979 & 4.3500 & 4.3200 & 104.0000 & 0 \\
\hline MU07 & ST.MURUMBA & \begin{tabular}{|l}
$9^{\circ} 56^{\prime} 39^{\prime \prime} \mathrm{N}$ \\
$8^{\circ} 52^{\prime} 00^{\prime \prime} \mathrm{E}$ \\
\end{tabular} & 28.000 & 135.0000 & 3.0000 & 123.4000 & 0.9141 & 5.6700 & 1.0300 & 64.0000 & 0 \\
\hline MU08 & TUDUN WADA & $\begin{array}{|ll|}9^{\circ} 54^{\prime} & 19^{\prime \prime} \mathrm{N} \\
8^{\circ} 52^{\prime} & 43^{\prime \prime} \mathrm{E} \\
\end{array}$ & 24.000 & 135.0000 & 3.0000 & 116.2000 & 0.8607 & 4.8600 & 4.4600 & 101.0000 & 0 \\
\hline MU09 & SOT GYEL & $\begin{array}{lll}09^{\circ} 48^{\prime} & 03^{\prime \prime} \mathrm{N} \\
08^{\circ} 50^{\prime} & 16^{\prime \prime} & \mathrm{E} \\
\end{array}$ & 27.300 & 135.0000 & 3.0000 & 134.0000 & 0.9926 & 5.2400 & 8.4000 & 122.0000 & 1 \\
\hline MU10 & \begin{tabular}{|l} 
BAUCHI \\
JUNCTION
\end{tabular} & $\begin{array}{lll}09^{\circ} 57^{\prime} & 32 ” \\
08^{\circ} & 53 & \\
\end{array}$ & 28.900 & 135.0000 & 3.0000 & 120.0000 & 0.8889 & 4.4300 & 4.5700 & 89.0000 & 0 \\
\hline MU11 & \begin{tabular}{|l|} 
RAYFIELD \\
RESORT
\end{tabular} & $\begin{array}{l}09^{\circ} 50^{\prime} 47.9^{\prime \prime} \mathrm{N} \\
08^{\circ} 53^{\prime} 29.2^{\prime \prime} \mathrm{E}\end{array}$ & 28.400 & 135.0000 & 3.0000 & 119.6100 & 0.886 & 5.7300 & 4.3300 & 101.0000 & 1 \\
\hline MU12 & ZAWAN & $\begin{array}{lll}09^{\circ} 46 & 18.9 ” & \mathrm{~N} \\
08^{\circ} 52^{\prime} & 10.4 ” \mathrm{E}\end{array}$ & 26.700 & 135.0000 & 3.0000 & 110.9980 & 0.8162 & 6.1000 & 4.2300 & 99.0000 & 1 \\
\hline MU13 & TCNN & 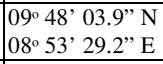 & 26.000 & 135.0000 & 3.0000 & 109.9980 & 0.8148 & 6.1500 & 4.2300 & 96.0000 & 0 \\
\hline MU14 & SOT GYEL & 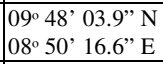 & 27.000 & 135.0000 & 3.0000 & 119.7000 & 0.8867 & 5.8500 & 4.5900 & 81.0000 & 1 \\
\hline MU15 & ANGUL DEE & & 28.100 & 135.000 & 3.0000 & 124.3050 & 0.9208 & 6.0000 & 5.3100 & 128.000 & 0 \\
\hline
\end{tabular}

Table 3. Table showing the value of the linear attenuation, half value layer and mass attenuation of the water samples.

\begin{tabular}{|c|c|c|c|c|c|c|}
\hline Sample ID & Location & $\begin{array}{l}\text { Geographical } \\
\text { Coordinate }\end{array}$ & $\begin{array}{l}\text { Linear } \\
\text { Attenuation } \\
\mu_{\exp }\left(\mathbf{c m}^{-1}\right)\end{array}$ & $\begin{array}{l}\text { Half } \\
\text { Value } \\
\text { Layer } \\
(\mathbf{c m})\end{array}$ & $\begin{array}{l}\text { Mass } \\
\text { Attenuation } \\
(\boldsymbol{\mu} / \mathbf{P})\end{array}$ & \% Error \\
\hline MU01 & $\mathrm{Du}$ & NA & 0.3390 & 2.0440 & 0.4170 & -2.1951 \\
\hline MU02 & GadaBiyu & $\begin{array}{l}09^{\circ} 55^{\prime} 44^{\prime \prime} \mathrm{N} \\
08^{\circ} 52^{\prime} 18^{\prime \prime} \mathrm{E}\end{array}$ & 0.3390 & 2.0440 & 0.4167 & -2.1951 \\
\hline MU03 & JUTH & $\begin{array}{l}09^{\circ} 54^{\prime} 59^{\prime \prime} \mathrm{N} \\
08^{\circ} 533^{\prime} 27^{\prime \prime} \mathrm{E}\end{array}$ & 0.2970 & 2.3330 & 0.3786 & -1.7992 \\
\hline MU04 & Angul Dee & NA & 0.4278 & 1.6199 & 0.4616 & -3.0320 \\
\hline MU05 & Yan Trailer & NA & 0.2878 & 2.4080 & 0.3700 & -1.7125 \\
\hline MU06 & JENTA & $\begin{array}{l}9^{\circ} 55^{\prime} 7^{\prime \prime} \mathrm{N} \\
8^{\circ} 52^{\prime} 46^{\prime \prime} \mathrm{E}\end{array}$ & 0.3869 & 1.7912 & 0.4309 & -2.6466 \\
\hline MU07 & ST.MURUMBA & $\begin{array}{l}9^{\circ} 56^{\prime} 39^{\prime \prime} \mathrm{N} \\
8^{\circ} 52^{\prime} 00^{\prime \prime} \mathrm{E}\end{array}$ & 0.3074 & 2.2543 & 0.3363 & -1.8972 \\
\hline MU08 & TUDUN WADA & $\begin{array}{l}9^{\circ} 54^{\prime} 19^{\prime \prime} \mathrm{N} \\
8^{\circ} 52^{\prime} 43^{\prime \prime} \mathrm{E}\end{array}$ & 0.3740 & 1.8529 & 0.4345 & -2.5250 \\
\hline MU09 & SOT GYEL & $\begin{array}{l}09^{\circ} 48^{\prime} 03 \text { 03” N } \\
08^{\circ} 50^{\prime} 16^{\prime \prime} \mathrm{E}\end{array}$ & 0.4743 & 1.4611 & 0.4778 & -3.4703 \\
\hline MU10 & BAUCHI JUNCTION & $\begin{array}{l}09^{\circ} 57^{\prime} 32^{\prime \prime} \mathrm{N} \\
08^{\circ} 53 \text { ' } 22 \text { " E }\end{array}$ & 0.3622 & 1.9133 & 0.4075 & -2.4137 \\
\hline MU11 & RAYFIELD RESORT & $\begin{array}{l}09^{\circ} 50^{\prime} 47.9^{\prime \prime} \mathrm{N} \\
08^{\circ} 53,29.2 ” \mathrm{E}\end{array}$ & 0.3743 & 1.8515 & 0.4225 & -2.5278 \\
\hline MU12 & ZAWAN & $\begin{array}{l}09^{\circ} 46^{\prime} 18.9^{\prime \prime} \mathrm{N} \\
08^{\circ} 52^{\prime} 10.4 \text { ' E }\end{array}$ & 0.3505 & 1.9772 & 0.4294 & -2.3035 \\
\hline MU13 & TCNN & $\begin{array}{l}09^{\circ} 48^{\prime} 03.9^{\prime \prime} \mathrm{N} \\
08^{\circ} 53 \text { '29.2” E }\end{array}$ & 0.3505 & 1.9772 & 0.4302 & -2.3035 \\
\hline MU14 & SOT GYEL & $\begin{array}{l}09^{\circ} 48^{\prime} 03.9^{\prime \prime} \mathrm{N} \\
08^{\circ} 50^{\prime} 16.6 ” \mathrm{E}\end{array}$ & 0.3622 & 1.9133 & 0.4085 & -2.4138 \\
\hline MU15 & ANGUL DEE & $\mathrm{Na}$ & 0.4273 & 1.6218 & 0.4641 & -3.0273 \\
\hline
\end{tabular}




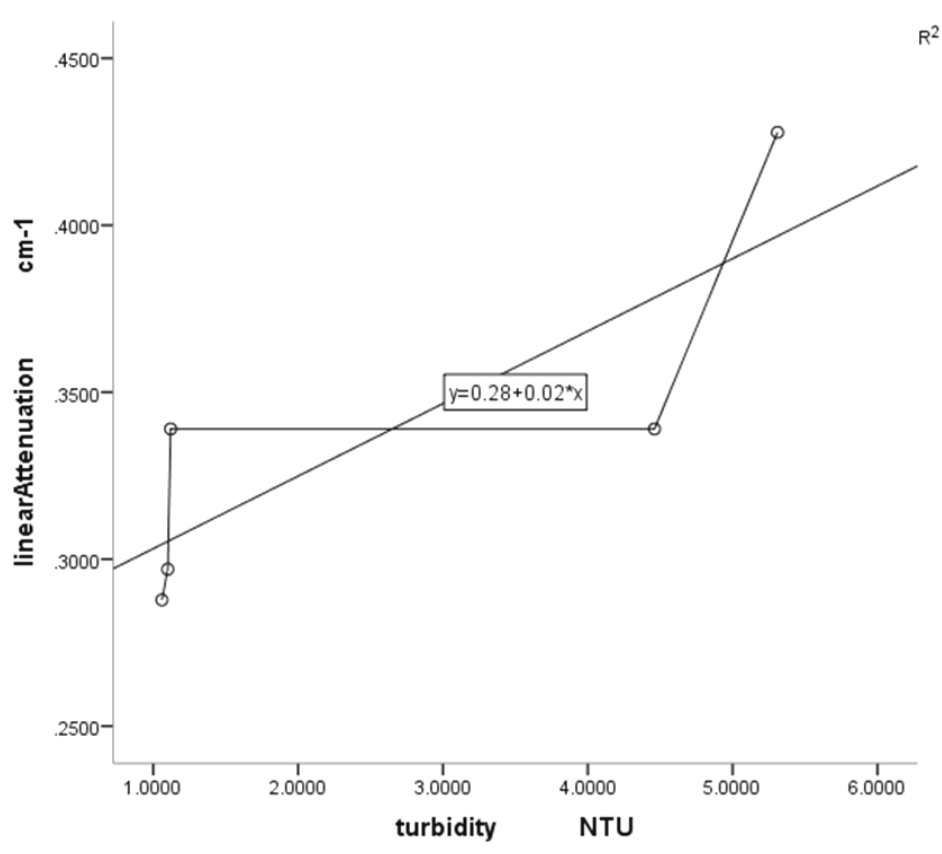

$R^{2}$ Linear $=0.677$

Graph of linear attenuation against turbidity for borehole.

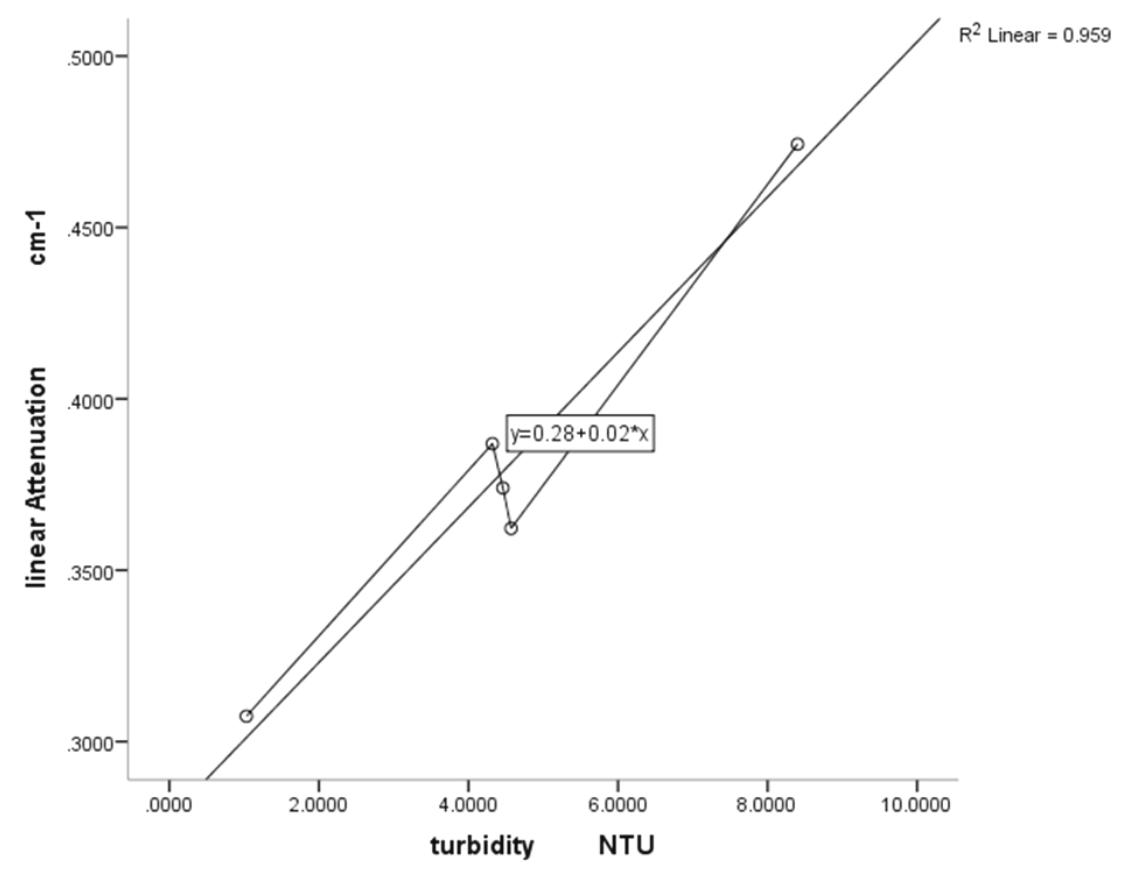

Figure 1. Graph of linear attenuation against turbidity for well. 


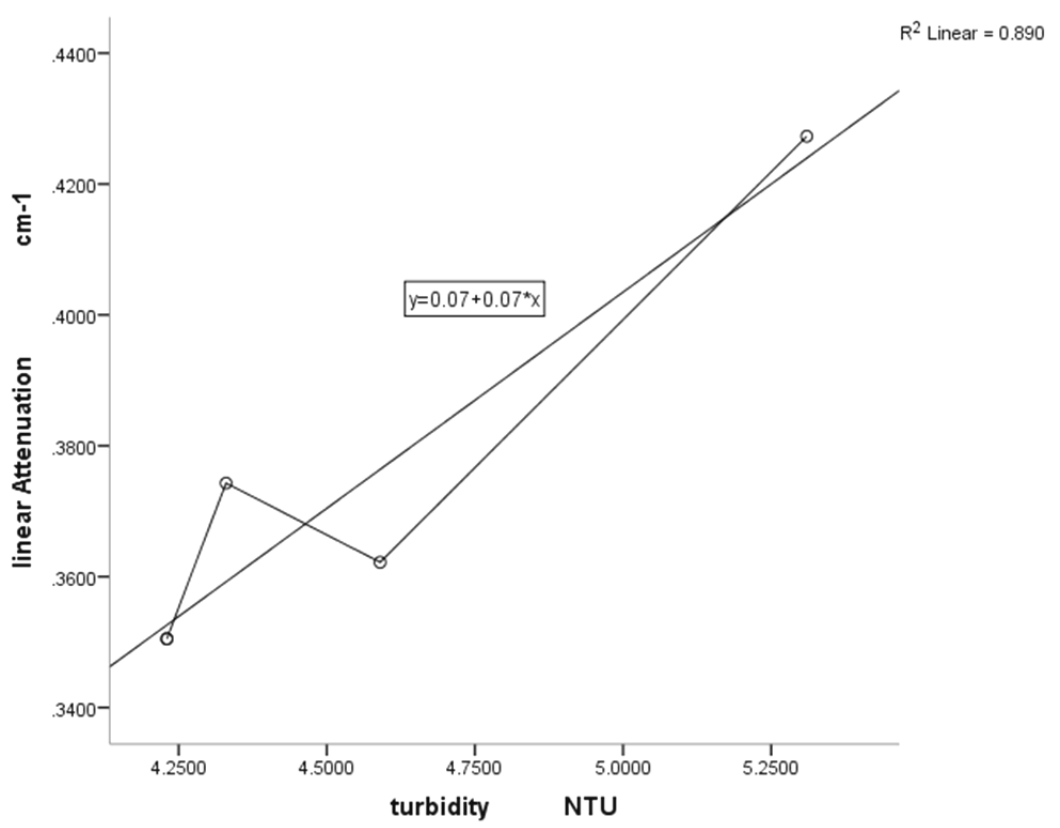

Figure 2. Graph of linear attenuation against turbidity for pond.

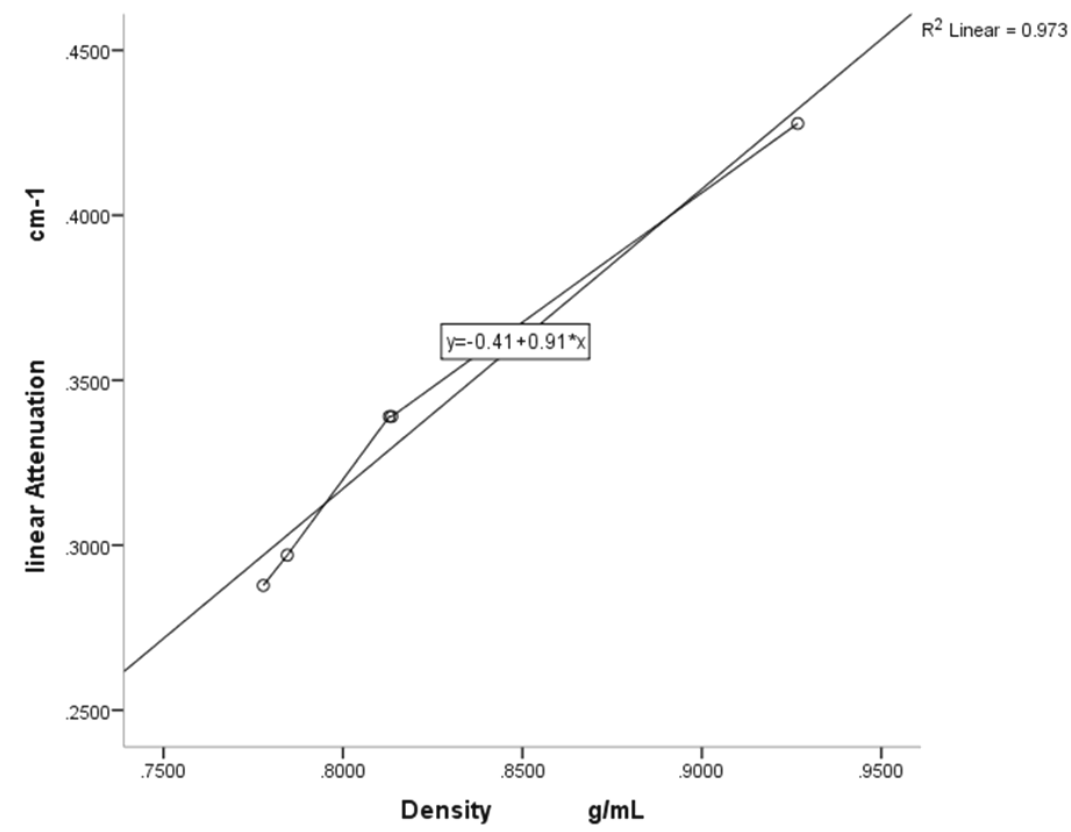

Figure 3. Graph of linear attenuation coefficient against density for borehole. 


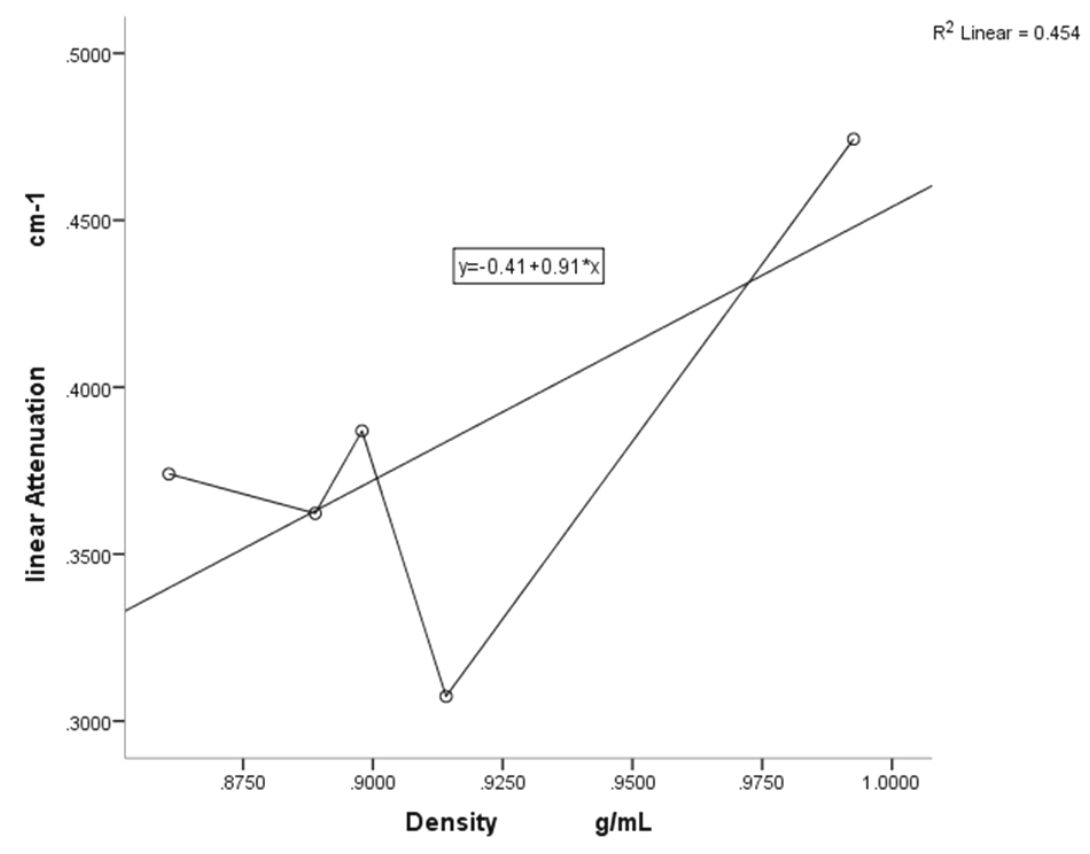

Figure 4. Graph of linear attenuation coefficient against density for well.

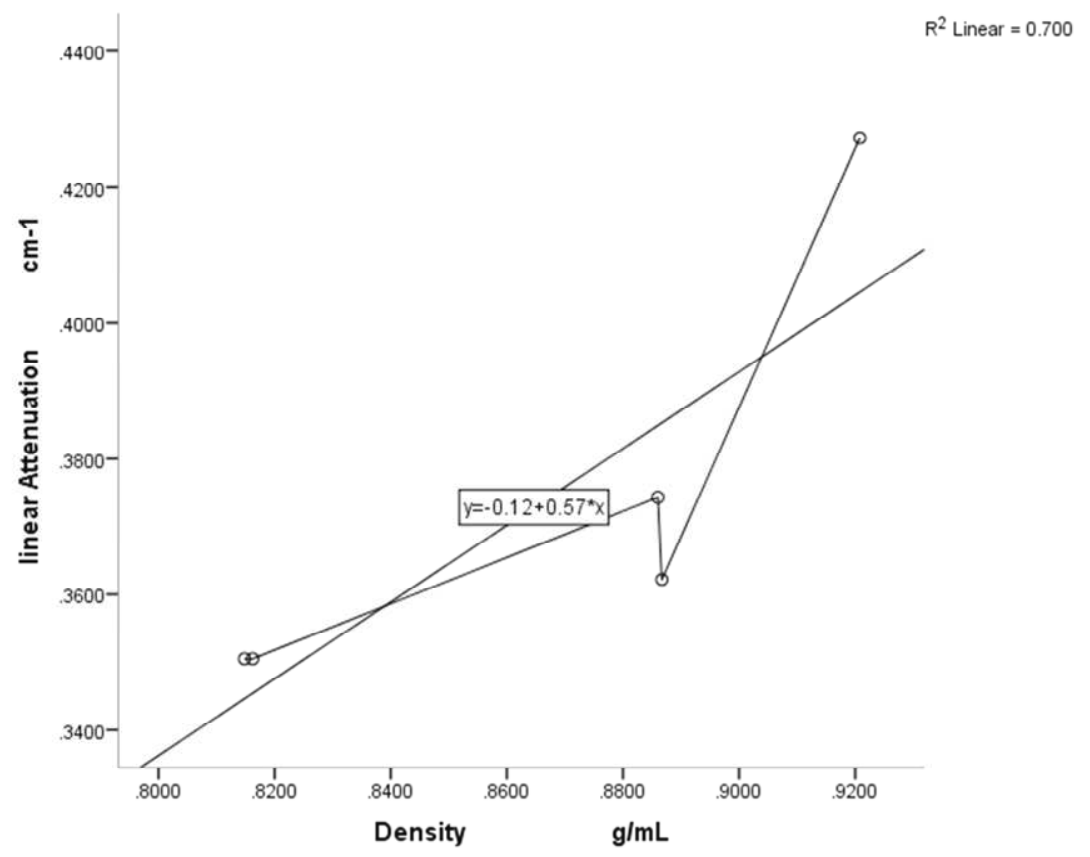

Figure 5. Graph of linear attenuation coefficient against density of pond. 


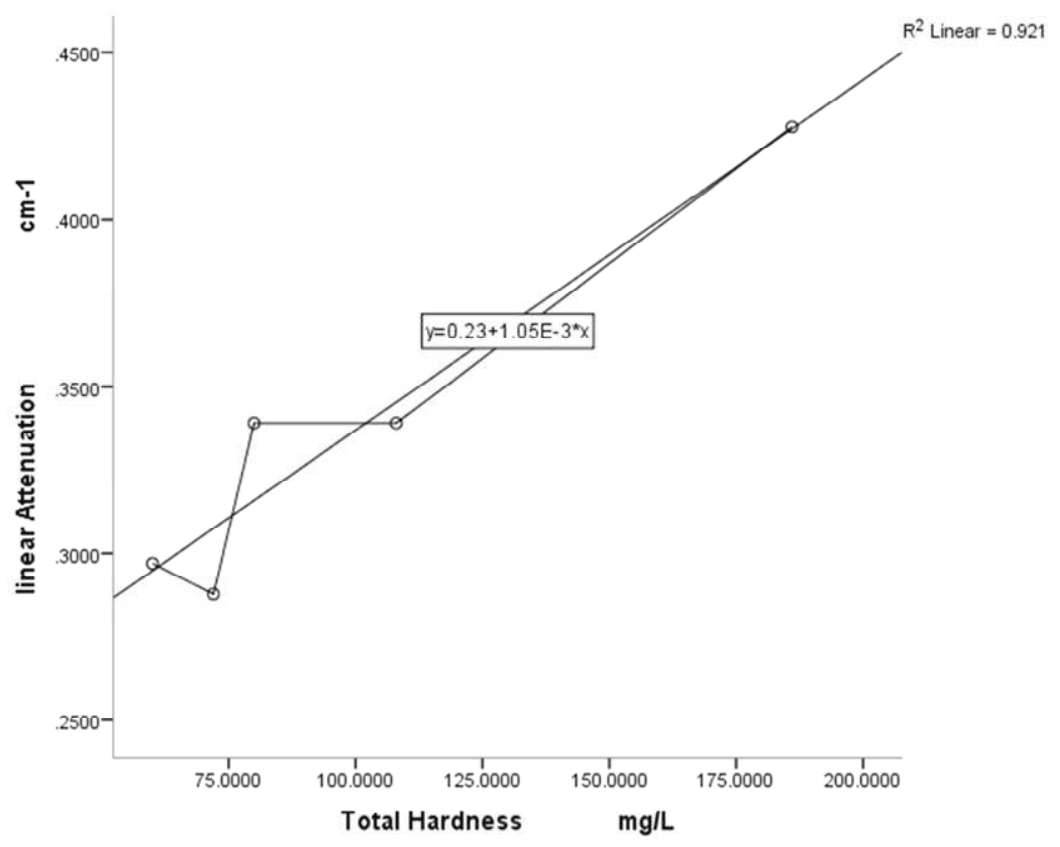

Figure 6. Graph of linear attenuation against total hardness for borehole.

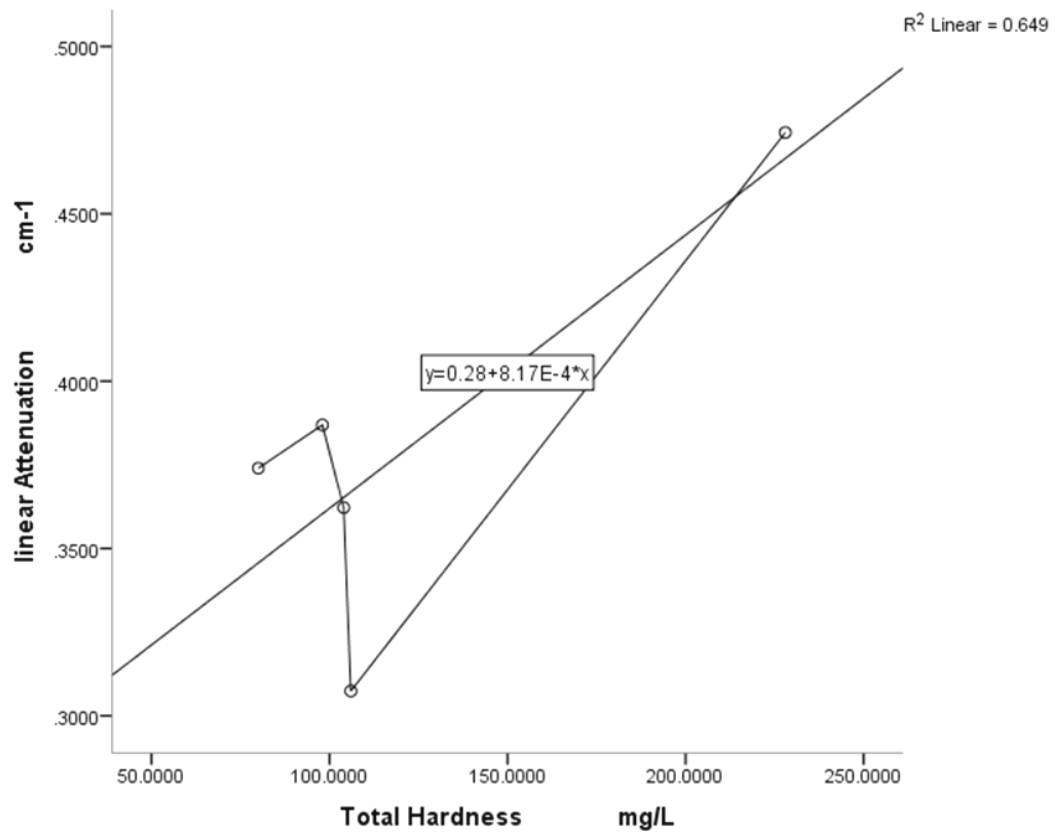

Figure 7. Graph of linear attenuation against total hardness for well. 


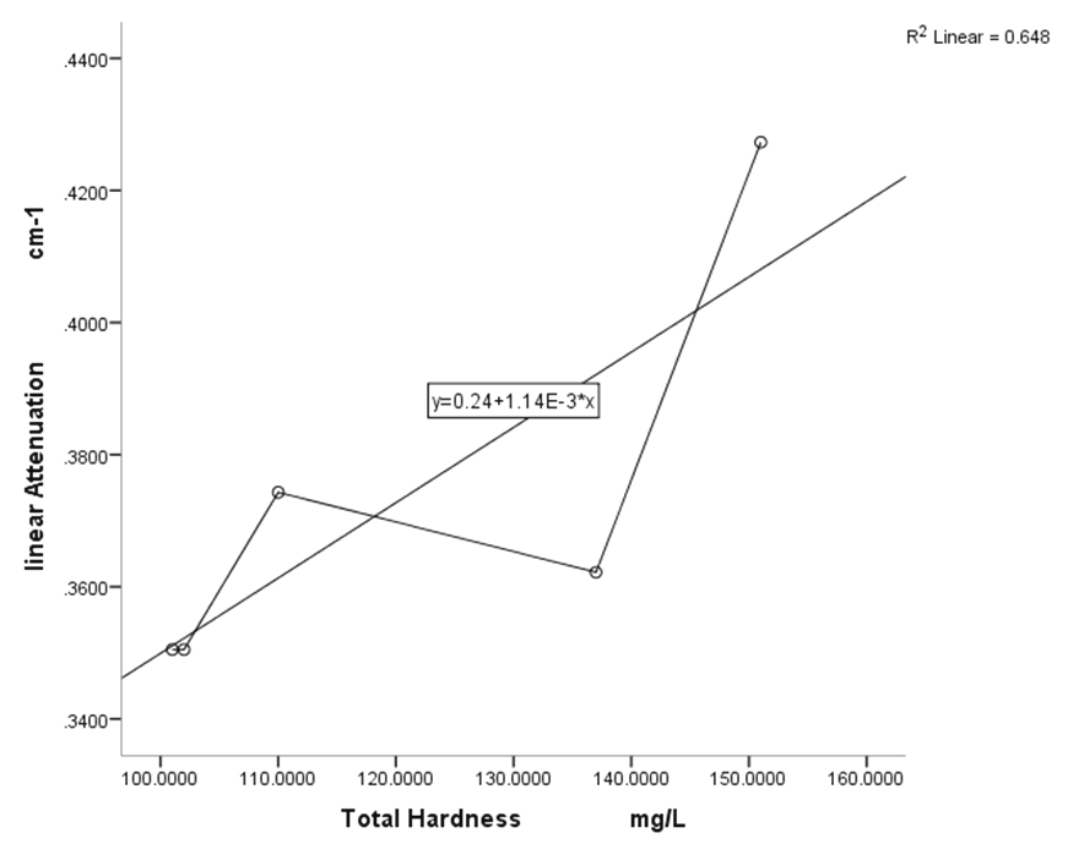

Figure 8. Graph of linear attenuation coefficient against total hardness for pond.

\section{Discussions}

From the results obtained we see a correlation between linear attenuation and turbidity, with a least square regression value $\mathrm{R}^{2}$ of $0.677,0.959,0.890$ for borehole, well and pond in that order. According to WHO, water is safe for consumption when the turbidity level is in the range of 0.3-5.0 NTU, we were able to deduce its corresponding linear attenuation coefficient value in the range of $0.0241 \mathrm{~cm}^{-1}-0.4023 \mathrm{~cm}^{-1}$ which can ascertain the quality of water, values above or below this range may be as a result of rock particles present in the water, cloudy nature of the water. We found a correlation value between linear attenuation coefficients and density of water with a least square regression value of $0.973,0.454,0.700$ for borehole, well, and pond respectively, this value was as a result of the mass and volume of this water. It was also seen that a correlation between linear attenuation and total hardness of water was gotten as 0.921 , $0.649,0.648$ for borehole, well and pond in that order. Therefore by the analysis made, borehole water samples collected from this location is the best for consumption compared to pond water because of their variation of linear attenuation, total hardness, turbidity and density of the various samples. It is clearly seen that by the attenuation of 
various water samples, one can be able to deduce which water is safe because of the relationship of all comparative test of the water.

\section{References}

[1] A. F. Abimbola, A. M. Odukoya and O. K. Adesanya, The environmental impact assessment of waste disposal site on ground water in Oke-Ado, Lagos, Southwestern Nigeria, Proc. 15th Annual Conf. Nigerian Association Hydrogeologists, Kaduna, Nigeria, 2002, pp. 42.

[2] O. J. Achadu, F. E. Ako and C. L. Dalla, Quality assessment of stored harvested rainwater in Wukari, North-Eastern Nigeria: impact of storage media, Journal of Environmental Science, Toxicology and Food Technology 7(5) (2013), 25-32. https://doi.org/10.9790/2402-0752532

[3] I. M. Adekunle, T. A. Arowolo, N. P. Ndahi, B. Bello and D. A. Owolabi, Chemical characteristics of humic acids in relation to lead, copper and cadmium levels in contaminated soil of South West Nigeria, Annals of Environmental Science 1 (2007), 2334 .

[4] M. O. Aremu, B. L. Gav, O. D. Opaluwa, B. O. Atolaiye, P. C. Madu and D. U. Sangari, Assessment of physiochemical contaminants in water and fishes from selected rivers in Nasarawa state, Nigeria, Res. J. Chem. Sci. 1(4) (2011), 6-17.

[5] U. V. Biradar and S. M. Dongarge, Linear and mass absorption coefficient of methanol solution of oxalic acid by varying concentration at $0.662 \mathrm{MeV}$ gamma energy by varying concentration, International Journal of Scientific \& Engineering Research 9(1) (2018), 853-859.

[6] Food \& Agricultural Organization (FAO), Chemical Analysis Manual for Food and Water, 5th ed., Vol. 1, FAO, Rome 1997, pp. 20-26.

[7] J. H. Hubbell, Photon mass attenuation and energy-absorption coefficients, The International Journal of Applied Radiation and Isotopes 33 (1982), 1269-1290. https://doi.org/10.1016/0020-708X(82)90248-4

[8] Komal Kirandeep, Parveen Bala and Amandeep Sharma, Determination of attenuation coefficient and water content of Broccoli leaves using beta particles, International Journal of Computer Applications (2015), 25-28.

[9] R. D. Pawar, G. P. Waghulade and A. K. Patil, AJCER 5(1-2) (2012), 71-73. 